\title{
Enhanced fear expression in a psychphathological mouse model of trait anxiety: pharmacological interventions
}

\author{
Markus Hauschild", Simone B Sartori ${ }^{1}$, Mirjam Bunck ${ }^{2,3}$, Stefano Gaburro ${ }^{1}$, Rainer Landgraf ${ }^{2}$, Nicolas Singewald ${ }^{1 *}$ \\ From 16th Scientific Symposium of the Austrian Pharmacological Society (APHAR) \\ Vienna, Austria. 25-27 November 2010
}

\section{Background}

The propensity to develop an anxiety disorder is thought to be determined by genetic and environmental factors. Here we investigated the relationship between an extreme genetic predisposition to trait anxiety and experience-based learned fear in a psychopathological mouse model.

\section{Methods}

Male CD-1 mice selectively bred for either high (HAB) or normal (NAB) anxiety-related behaviour on the elevated plus maze were subjected to classical fear conditioning.

\section{Results}

Both mouse lines learned to fear an initially neutral stimulus (CS) being indicated by increasing freezing levels. $24 \mathrm{~h}$ later, HAB mice displayed more pronounced freezing responses to both the context and cue CS compared with NAB mice, suggesting that trait anxiety determines stronger fear memory and/or a weaker ability to inhibit fear responses in the HAB line. Interestingly, already $1 \mathrm{~h}$ and $6 \mathrm{~h}$ after fear conditioning, freezing levels were high in HAB mice but not in NAB mice. The enhanced fear response of $\mathrm{HAB}$ mice was attenuated by treatment with either the $\alpha_{2,3,5}$-subunit-selective benzodiazepine partial agonist L-838,417, corticosterone or the selective neurokinin-1 receptor antagonist L-822,429.

\footnotetext{
* Correspondence: nicolas.singewald@uibk.ac.at

'Department of Pharmacology and Toxicology, Institute of Pharmacy and Center for Molecular Biosciences Innsbruck (CMBI), University of Innsbruck, 6020 Innsbruck, Austria

Full list of author information is available at the end of the article
}

\section{Conclusions}

Overall, the HAB mouse line may represent an interesting model (i) for identifying biological factors underlying misguided conditioned fear responses and (ii) for studying novel pharmacotherapies for patients with anxiety disorders, including post-traumatic stress disorder and phobias.

\section{Acknowledgements \\ Supported by the Austrian Science Fund FWF NFN-S-102 (NS).}

\section{Author details}

'Department of Pharmacology and Toxicology, Institute of Pharmacy and Center for Molecular Biosciences Innsbruck (CMBI), University of Innsbruck, 6020 Innsbruck, Austria. ${ }^{2}$ Department of Behavioral Neuroendocrinology, Max Planck Institute of Psychiatry, 80804 Munich, Germany. ${ }^{3}$ Affectis

Pharmaceuticals AG, 82152 Martinsried, Germany.

Published: 16 November 2010

doi:10.1186/1471-2210-10-S1-A5

Cite this article as: Hauschild et al: Enhanced fear expression in a psychphathological mouse model of trait anxiety: pharmacological interventions. BMC Pharmacology 2010 10(Suppl 1):A5.

Submit your next manuscript to BioMed Central and take full advantage of:

- Convenient online submission

- Thorough peer review

- No space constraints or color figure charges

- Immediate publication on acceptance

- Inclusion in PubMed, CAS, Scopus and Google Scholar

- Research which is freely available for redistribution 